J. Dairy Sci. 96:2521-2535

http://dx.doi.org/10.3168/jds.2012-6145

(c) American Dairy Science Association ${ }^{\circledR}, 2013$.

\title{
Storage characteristics, nutritive value, energy content, and in vivo digestibility of moist, large rectangular bales of alfalfa-orchardgrass hay treated with a propionic acid-based preservative ${ }^{1}$
}

\author{
W. K. Coblentz, ${ }^{* 2}$ K. P. Coffey, $†$ A. N. Young, $†$ and M. G. Bertram $\ddagger$ \\ *US Department of Agriculture-Agricultural Research Service (USDA-ARS), US Dairy Forage Research Center, Marshfield, WI 54449 \\ †Department of Animal Science, University of Arkansas, Fayetteville 72701 \\ ¥Superintendent, University of Wisconsin Arlington Agricultural Research Station, Arlington 53911
}

\begin{abstract}
Unstable weather, poor drying conditions, and unpredictable rainfall events often place valuable hay crops at risk. Recent research with large round bales composed of alfalfa (Medicago sativa L.) and orchardgrass (Dactylis glomerata L.) has shown that these large-bale packages are particularly sensitive to spontaneous heating and dry matter (DM) losses, as well as other undesirable changes with respect to forage fiber, protein, and energy density. Various formulations of organic acids have been marketed as preservatives, normally for use on hays that are not desiccated adequately in the field to facilitate safe bale storage. Our objectives for this study were to (1) evaluate the efficacy of applying a commercial (buffered) propionic acid-based preservative at 3 rates $(0,0.6$, and $1.0 \%$ of wet-bale weight) to hays baled at 3 moisture concentrations (19.6, 23.8, and $27.4 \%$ ) on the subsequent storage characteristics and poststorage nutritive value of alfalfa-orchardgrass forages packaged in large rectangular $(285-\mathrm{kg})$ bales, and then (2) evaluate the in vivo digestibility of these hays in growing lambs. Over a 73-d storage period, the preservative was effective at limiting spontaneous heating in these hays, and a clear effect of application rate was observed for the wettest $(27.4 \%)$ bales. For drier hays, both acid-application rates $(1.0$ and $0.6 \%)$ yielded comparable reductions in heating degree days $>30^{\circ} \mathrm{C}$ relative to untreated controls. Reductions in spontaneous heating could not be associated with improved recovery of forage DM after storage. In this study, most changes in nutritive value during storage were related to measures of spontaneous heating in simple linear regression relationships; this suggests that the mod-
\end{abstract}

Received September 10, 2012

Accepted December 6, 2012.

${ }^{1}$ Mention of trade names or commercial products in this article is solely for the purpose of providing specific information, and does not imply either recommendation or endorsement by the US Department of Agriculture.

${ }^{2}$ Corresponding author: wayne.coblentz@ars.usda.gov est advantages in nutritive value resulting from acid treatment were largely associated with perturbations of normal heating patterns during bale storage. Although somewhat erratic, apparent digestibilities of both DM $\left(\mathrm{Y}=-0.0080 \mathrm{x}+55.6 ; \mathrm{R}^{2}=0.45\right)$ and organic matter $\left(\mathrm{Y}=-0.0085 \mathrm{x}+55.5 ; \mathrm{R}^{2}=0.53\right)$ evaluated in growing lambs were also directly related to heating degree days in simple linear relationships. Based on these data, applying propionic acid-based preservatives to large rectangular bales is likely to provide good insurance against spontaneous heating during storage, as well as modest benefits with respect to nutritive value and digestibility.

Key words: alfalfa, apparent digestibility, hay, spontaneous heating

\section{INTRODUCTION}

Unstable weather, poor drying conditions, and unpredictable rainfall events often place valuable hay crops at risk. These interrelated factors often force producers to choose between rain damage to their valuable hay crops and baling at moisture concentrations that exceed recommended thresholds for safe storage. Recent research with alfalfa (Medicago sativa L.)-orchardgrass (Dactylis glomerata L.) hays has demonstrated that large round bales are particularly sensitive to spontaneous heating and DM losses (Coblentz and Hoffman, 2009a), as well as other undesirable changes in various forage fiber components (Coblentz and Hoffman, 2009b), protein (Coblentz et al., 2010), and calculated energy density (Coblentz and Hoffman, 2010). These processes are known commonly to be initiated via microorganisms associated with the hay, thereby causing respiration of plant DM (primarily nonstructural carbohydrates) into $\mathrm{CO}_{2}$, water, and heat (Rotz and Muck, 1994). In addition, Coblentz and Hoffman (2009a) determined that the relationship between heating degree days (HDD), an index that integrates both the magnitude and duration of heating during bale storage, and initial bale moisture was positive and linear for alfalfa-orchardgrass 
hays packaged in 0.9- and 1.2-m diameter round bales. However, the relationship became curvilinear in larger (1.5-m) diameter bales, thereby accelerating the accumulation of HDD per unit of initial bale moisture [Y $\left.=0.99 \mathrm{x}^{2}-82\right]$. The threshold bale moisture for satisfactory storage of traditional $(45-\mathrm{kg})$ small rectangular bales has been established for decades (20\%; Collins et al., 1987), but this threshold is too moist for large hay packages that may weigh $500 \mathrm{~kg}$ or more. Obviously, these factors create a management dilemma for hay and livestock producers because the cost and availability of labor has necessitated the use of large hay packages on many farms, but these improved labor efficiencies often are offset by the increased sensitivity of large hay packages to spontaneous heating. As such, a need exists for proactive action to reduce or eliminate spontaneous heating in large bales to maximize the preservation of nutrients that support livestock production.

For many years, various formulations of organic acids have been marketed as preservatives, most specifically for use on hays that could not be field desiccated to moisture concentrations dry enough to reduce or eliminate natural heating. These preservatives are often propionic acid-based products that are formulated to create an unfavorable environment for growth of molds, and are buffered to limit oxidative damage to expensive farm equipment. In the past, these types of products have been applied to small rectangular $(45-\mathrm{kg})$ bales with some success (Sheaffer and Clark, 1975; Rotz et al., 1991; Buckmaster and Heinrichs, 1993). More recent evaluations of these products for large rectangular bales of alfalfa (Shinners, 2000) suggested that bales treated with a propionic acid-based product maintained greater moisture concentrations during storage; previously, this has been associated with the hygroscopic nature of propionic acid (Rotz et al., 1991). This observation also was reported by Coblentz and Bertram (2012), who found elevated poststorage moisture concentrations in acid-treated large round bales of alfalfa hay compared with untreated control hays. Furthermore, acid treatment generally reduced the accumulation of HDD during the first $28 \mathrm{~d}$ of storage, but accumulations of HDD across the entire storage period were greater for acid-treated bales compared with untreated controls whenever the initial bale moisture exceeded 27.7\% (Coblentz and Bertram, 2012). Although acid treatment clearly perturbed normal heating patterns in these large round-bale packages, overall improvements in poststorage nutritive value were very limited. It remains unclear whether these marginal responses to acid treatment were related to the (round) bale type, or the result of other factors. Our objectives for this study were to (1) evaluate the efficacy of applying a commercial buffered propionic acid-based preservative at 3 rates $(0,0.6$, and $1.0 \%$ of wet bale weight $)$ to hays baled at 3 moisture concentrations $(19.6,23.8$, and $27.4 \%)$ on the subsequent storage characteristics and poststorage nutritive value of alfalfa-orchardgrass hays packaged in large rectangular $(285-\mathrm{kg})$ bales, and (2) evaluate the in vivo digestibility of these hays in growing lambs.

\section{MATERIALS AND METHODS}

\section{Hay Storage Trial}

Baling Procedures. Forage for this experiment was obtained from a 7.1-ha stand of Pioneer 55V48 alfalfa (Pioneer Hi-Bred International Inc., Johnston, IA) and Extend orchardgrass (Allied Seed LLC, Nampa, ID) growing on a Marshfield silt loam (fine-loamy, mixed, frigid, Typic Ochraqualfs) soil type at the University of Wisconsin Marshfield Agricultural Research Station (located near Stratford; $44^{\circ} 7^{\prime} \mathrm{N}, 90^{\circ} 1^{\prime} \mathrm{W}$ ). During 2010, the second cutting of forage from this site was mowed with a Case International mower-conditioner (model 8830; J. I. Case Co., Racine, WI) at 1400 h on August 3 , 2010. Immediately after mowing, 3 samples of mowed forage $(\sim 3,000 \mathrm{~g})$ were obtained by walking the field in a zigzag pattern stopping periodically to take grab samples at random locations. These samples were then dried to constant weight under forced air at $55^{\circ} \mathrm{C}$, hand sorted by species, and then weighed to determine species composition (mean \pm SD) by dry weight (alfalfa, $94.9 \pm 0.66 \%$; orchardgrass, $4.0 \pm 0.94 \%$; and other species, $1.1 \pm 0.29 \%)$. Hay was tedded at $1400 \mathrm{~h}$ on August 4, and again at $1000 \mathrm{~h}$ on August 6, before adjacent rows were rolled together at $1500 \mathrm{~h}$ the same day with a side-delivery rake. Immediately thereafter $(1545 \mathrm{~h}), 160.8 \times 0.8 \times 1.7-\mathrm{m}$ bales $($ mean weight $=$ $292 \mathrm{~kg}$ ) were produced with a large-rectangular baler (model 100; Deere and Co., Moline, IL) equipped with a preservative applicator (Harvest Tec Inc., Hudson, WI) and an in-line flow meter to measure the volume of preservative output applied to each bale. The mean moisture concentration for these bales was $27.4 \%$, henceforth designated as high moisture (HM). In this group of HM bales, 4 bales received a buffered propionic-based preservative (FRESH CUT Plus; Kemin AgriFoods North America Inc., Des Moines, IA) applied at $1.0 \%$ of wet bale weight. Similarly, 5 bales received the same preservative $0.6 \%$ of wet bale weight, whereas the remaining 7 bales were untreated and served as control hays.

These baling procedures were repeated at $1840 \mathrm{~h}$ the same day when the mean forage moisture concentration was $23.8 \%$ (medium moisture, $\mathbf{M M}$ ), and a total of 10 bales (mean weight $=284 \mathrm{~kg}$ ) were produced. Among these, 4 bales were made with the $1.0 \%$ preservative 
Table 1. Initial bale characteristics for large rectangular bales of alfalfa-orchardgrass hay

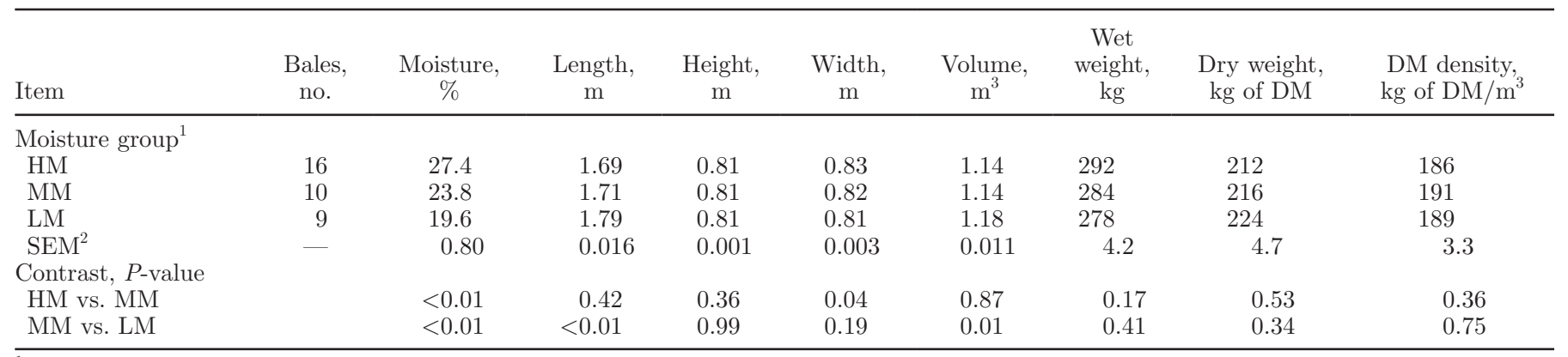

${ }^{1} \mathrm{HM}=$ high-moisture $(27.4 \%)$ bales; $\mathrm{MM}=$ medium-moisture $(23.8 \%)$ bales; $\mathrm{LM}=$ low-moisture (19.6\%) bales.

${ }^{2}$ Standard error of the main effect mean.

application level, whereas 3 each were made with the 0 (control) and $0.6 \%$ application rates. Similarly, a final baling group (low moisture, LM) consisting of 9 bales (mean weight $=278 \mathrm{~kg}$ ) was produced at $1530 \mathrm{~h}$ on August 7; the mean moisture concentration for LM bales was $19.6 \%$, and 3 bales were made at each preservative application level. During the baling process, an additional bale was produced and then discarded (no data recorded) whenever the preservative application level was changed from either the 1.0 or $0.6 \%$ level to the untreated control. This precaution was taken to ensure no contamination of untreated controls with the acid preservative. Based on the consistent topography across the field site, as well as the high percentage of alfalfa $(94.9 \%)$ in the mixed sward, no obvious basis existed for restricting randomization (blocking); therefore, bales were produced randomly throughout the field site.

Prestorage Sampling and Processing. Immediately after bales were produced, they were transported to the storage facility and weighed to the nearest 0.90 $\mathrm{kg}$ increment on a motorized feed cart equipped with load cells. Bales were positioned on top of individual wooden pallets located inside of an open-sided pole barn built with a concrete floor. Although bales/pallets were arranged in rows to conserve space, approximately $7.5 \mathrm{~cm}$ of air space was maintained between each bale to avoid any cross-contamination of moisture, or transfer of heat between bales. Bale height, width, and length were determined with a tape measure, thereby allowing subsequent calculation of bale volume and DM density. Initially, all bales were sampled with six 0.61-m deep core samples (0.025-m diameter) that were taken from one end of each bale using a Uni-Forage Sampler (Star Quality Samplers, Edmonton, AB, Canada). The 6 initial core samples were taken with a 2 (vertical) $\times 3$ (horizontal) grid pattern. Bales produced by our baler had 4 tie strings; therefore, this sampling pattern consisted of 2 core samples between each pair of tie strings with each sampling location approximately 26 $\mathrm{cm}$ apart, and a similar distance from the bale surface. These sampling procedures produced a collective sample from each bale weighing approximately $200 \mathrm{~g}$, which was placed in a paper bag, and then dried to constant weight under forced air at $55^{\circ} \mathrm{C}$ to determine the prestorage concentration of moisture for that bale. Spray-foam insulation was used to fill all (6) holes created during this initial sampling process to prevent air, sunlight, and moisture from having direct access into the bale core, and to eliminate any easy conduits for quick dissipation of heat and moisture from the bales. All prestorage bale characteristics are summarized in Table 1.

Temperature Measurements. All bales were fitted with a thermocouple positioned near the geometric center of each bale. Internal bale temperatures were measured with an Omega 450 AKT Type K thermocouple thermometer (Omega Engineering Inc., Stamford, CT), and recorded daily for $73 \mathrm{~d}$. Heating degree days $>30^{\circ} \mathrm{C}$ were determined by calculating the daily increment that the internal bale temperature exceeded $30^{\circ} \mathrm{C}$; these daily assessments of HDD were then summed over the entire 73 -d storage period to produce the total HDD accumulated for each bale. On days when the internal bale temperature was $<30^{\circ} \mathrm{C}$, no HDD were recorded for that day. Therefore, HDD represents a single numeric response variable that integrates both the intensity and duration of heating for each bale across the entire storage period. Other temperature measurements reported include maximum internal bale temperature (MAX), as well as 40-d average bale temperature. The $40-\mathrm{d}$ basis for calculating average temperature was based on the observation that d 40 was the last day that any bale in the study accumulated HDD.

Poststorage Sampling and Processing. On October 19, 2010, all bales were measured on a poststorage basis for width, diameter, and final bale weight 
by methods similar to those described previously. At this time, each bale was sampled via nine $0.61-\mathrm{m}$ cores located at the opposite end of the bale from the initial (prestorage) assessment. Poststorage samples were composited by bale $(\sim 300 \mathrm{~g})$, and then dried in paper bags to constant weight under forced air at $55^{\circ} \mathrm{C}$, thereby allowing calculation of a final poststorage moisture concentration for each bale. This moisture concentration then was used to calculate the poststorage DM weight, DM density, and recovery of DM for each bale. Recoveries of DM were calculated on the basis of differences in bale weights (DM basis) determined before and after the 73-d storage period.

\section{Digestibility Trial}

At the conclusion of the 73-d storage period, 2 bales were selected from each of the 9 interactive baling treatments ( 3 bale moistures $\times 3$ preservative application rates) for further assessment of in vivo digestibility of these hays in growing lambs. In each interactive baling treatment, 3 to 7 replications (bales) were produced for the hay storage experiment; therefore, selection criteria were established to qualify specific bales for further study. Primarily, these criteria were based on (1) proximity of HDD accumulated in each selected bale to the overall interactive treatment mean and (2) the relative precision of accumulated HDD measurements between the 2 bales selected in each interactive treatment. Selected bales were loaded onto a covered flatbed trailer and transported by semi-truck (Roehl Transport Inc., Marshfield, WI) during the winter of 2010 to 2011 from the Marshfield Agricultural Research Station to the University of Arkansas in Fayetteville to complete the in vivo digestion phase of the project. At Fayetteville, bales were unloaded and stacked under roof in a metal storage building until initiation of the feeding trial.

All procedures for daily care and handling of sheep were approved by the University of Arkansas Animal Care and Use Committee (protocol no. 11055). Eighteen crossbred wethered lambs $(34.5 \pm 3.71 \mathrm{~kg})$ were obtained from one local producer, and each was a cross between black-faced (Suffolk/Hampshire) and Gulf Coast Native breeding. Lambs were weighed, dewormed with levamisole hydrochloride (Prohibit Soluble Drench Powder Anthelmintic; Agri Laboratories Ltd., St. Joseph, MO), and then placed randomly in individual $1.1 \times 1.5-\mathrm{m}$ pens constructed with expanded metal floors. Pens were located in an enclosed metal building equipped with ventilation fans, and each pen was equipped with a metal feeder and an automatic-nipple waterer. However, water also was provided for ad libitum consumption by each lamb via plastic pails placed in each pen. In vivo digestibility of the 9 interactive hay-preservative treatments was assessed in a 2-period digestion study, with each period lasting 18 d. During each experimental period, lambs were weighed, stratified by BW, and then allocated randomly such that 2 lambs were offered hays from each of the 9 interactive baling treatments. No lamb was assigned to the same dietary treatment during both experimental periods, and each pair of lambs offered any particular treatment during the first period were split such that they were offered different treatments during the second period. The center third of each selected bale was chopped to approximate 7.5-cm particle lengths (model 3915; US Bedding Chopper; US Farm Systems Inc., Janesville, WI) and offered to lambs in equal feedings (0800 and $1700 \mathrm{~h}$ ) at a cumulative rate of $2.2 \%$ of BW daily (as is basis). Our objective was to determine apparent digestibilities of forage components without the confounding effects created by allowing ad libitum intake; therefore, $2.2 \%$ of $\mathrm{BW}$ represented the maximum intake that could be maintained across all dietary treatments with negligible orts (Cochran and Galyean, 1994). Beginning on d 10 of each period, lambs were fitted with unzipped fecal collection bags to allow $1 \mathrm{~d}$ of acclimation to the bags before starting total fecal collections on d 11 and continuing for $7 \mathrm{~d}$. Feces were collected twice daily at 0800 and $1700 \mathrm{~h}$, weighed, and dried to constant weight under forced air at $55^{\circ} \mathrm{C}$ to determine total output of fecal DM over a 7-d period. Similarly, samples of each hay diet were gathered daily, dried to constant weight under forced air at $55^{\circ} \mathrm{C}$, and retained for subsequent analyses. Generally, diets were consumed completely by lambs (no orts); however, occasional refusals were gathered daily at $1630 \mathrm{~h}$, weighed, and then dried as described for diet and fecal samples. To calculate the apparent digestibility for each of the diets, a 7-d calculation of intake also was required; this was intentionally advanced by $2 \mathrm{~d}$ (d 9 through 16 ) relative to fecal collections to account for passage time through the digestive track. Between experimental periods, lambs were removed from their pens, weighed, and offered an alfalfa-orchardgrass hay as a group for $8 \mathrm{~d}$; during this time they also were allowed access to a fenced lot with a base sod of common bermudagrass [Cynodon dactylon (L.) Pers.] interspersed with broadleaf weeds. Before initiating the second experimental period, lambs were weighed again, and then allocated randomly to treatments.

\section{Laboratory Analyses}

Hay Storage Trial. Each dried pre- and poststorage hay sample was ground through a Thomas Model $4 \mathrm{Wi}$ ley Mill (Thomas Scientific, Swedesboro, NJ) equipped with a 1-mm screen, and then stored in sealed freezer 
bags pending analysis for nutritive value. Samples were analyzed for ash, forage fiber components, CP, neutral detergent-insoluble CP (NDICP), and acid detergentinsoluble CP (ADICP). Whole-plant ash content was determined by combusting 1.0-g hay samples in a muffle furnace at $500^{\circ} \mathrm{C}$ for $6 \mathrm{~h}$. The batch procedures outlined by Ankom Technology Corp. for an $\mathrm{ANKOM}^{200}$ fiber analyzer (Ankom Technology Corp., Macedon, NY) were used to sequentially determine concentrations of fiber components (NDF, ADF, hemicellulose, and lignin). During assessment of fiber composition, neither sodium sulfite nor $\alpha$-amylase was included in the NDF solution, nor were concentrations of the various fiber components adjusted to remove residual ash. Crude protein, as well as residual CP remaining in neutral detergent and acid detergent residues, was quantified by a rapid combustion procedure (AOAC International, 1998; method 990.03; Elementar Americas Inc., Mt. Laurel, NJ). For NDICP, sodium sulfite was omitted from the preliminary digestion step in neutral detergent because sodium sulfite actively cleaves disulfide bonds and dissolves cross-linked proteins (Van Soest et al., 1991). Hay samples were digested directly in acid detergent before determining ADICP content without preliminary sequential digestion in neutral detergent, based on the recommendations of Van Soest et al. (1991). All determinations of CP, including NDICP and ADICP, used a conversion factor of 6.25 to convert total $\mathrm{N}$ into $\mathrm{CP}$. In this study, NDICP and ADICP are reported and discussed on both a percentage of DM and CP basis. The summative model (Weiss et al., 1992; NRC, 2001) was used to calculate the energy density (TDN) of each hay sample based on appropriate inputs determined from the previously described procedures. The ADL option for calculating the truly digestible fiber subunit of TDN (Weiss et al., 1992; NRC, 2001) was used throughout all assessments of hays.

Digestion Trial. Dried diet, ort, and fecal samples were ground through a Wiley mill equipped with a 1-mm screen and analyzed for ash, NDF, CP, NDICP, and ADICP. Generally, all analyses were conducted as described previously, except that NDF was analyzed with sodium sulfite and $\alpha$-amylase added to the neutral detergent solution during the initial digestion step; sodium sulfite was included to remove keratinaceous residues (Van Soest et al., 1991), such as hair, which may confound fiber digestibility.

\section{Statistics}

Bale Characteristics. Pre- and poststorage bale characteristics were analyzed in a completely randomized design with unequal replication across treatments. Baling treatments were arranged as a $3 \times 3$ factorial arrangement of treatments with 3 initial bale-moisture groups (HM, MM, and LM) and 3 preservative application levels $(0,0.6$, or $1.0 \%)$. Mean separation was accomplished via logical orthogonal contrasts. For prestorage and poststorage assessments of bale characteristics, little evidence existed of interaction among main effects; therefore, contrasts were confined to evaluations of main effects only. These included (1) HM versus MM bales, (2) MM versus LM bales, (3) all acid-treated hays versus untreated controls, and (4) 1.0 versus $0.6 \%$ preservative applications. All statistical analyses for these response variables were performed with PROC GLM of SAS (SAS Institute, 2002).

Nutritive Value and Spontaneous Heating. Data for the nutritive value of experimental hays were analyzed as described previously for physical bale characteristics. On a prestorage basis, the nutritive value of experimental hays was largely unaffected by baling treatment; therefore, only the overall means for the 35 experimental bales are presented. On a poststorage basis, interactions of main effects were detected frequently. As a result, 2 contrasts were evaluated in each bale-moisture group: (1) all acid-treated hays versus untreated controls and (2) 1.0 versus $0.6 \%$ preservative application levels.

Intake and Apparent Digestibility by Lambs. Daily intakes and calculated apparent digestibilities for DM, OM, NDF, CP, NDICP, and ADICP were analyzed with an identical $3 \times 3$ factorial treatment structure described for bale characteristics and nutritive value using PROC MIXED of SAS (SAS Institute, 2002). Experimental period was included in the model, but was designated as a random effect. Sire effects also were included in the initial model, but did not differ and, therefore, were removed from the model. Contrasts were constructed in an identical manner to those described for indices of nutritive value.

Regressions of Nutritive Value and Apparent Digestibility on Spontaneous Heating. The relationships between changes for nutritive value during storage and heating characteristics for the 9 interactive baling treatments were determined by regressing the change in nutritive value (poststorage - prestorage) for NDF, ADF, hemicellulose, cellulose, lignin, ash, CP, NDICP, ADICP, and TDN $(\triangle \mathrm{NDF}, \triangle \mathrm{ADF}, \Delta$ hemicellulose, $\Delta$ cellulose, $\Delta$ lignin, $\Delta$ ash, $\Delta \mathrm{CP}, \Delta \mathrm{NDICP}, \Delta \mathrm{ADICP}$, and $\triangle T D N$, respectively) on heating indices (HDD and MAX) using linear, quadratic, and cubic polynomial models (PROC REG; SAS Institute, 2002). Selection of the appropriate polynomial model was dependent on a significant overall regression, as well as verification that all coefficients for polynomial terms differed from zero. Apparent total-tract digestibilities in lambs also were regressed linearly on HDD using PROC REG of 
SAS (SAS Institute, 2002). For all statistical analyses, significance was declared at $P=0.05$, unless otherwise indicated.

\section{RESULTS}

\section{Prestorage Bale Characteristics}

Physical characteristics of experimental bales determined on a prestorage basis are reported in Table 1. The main effect of preservative application rate, and its associated interaction with initial bale moisture, did not affect $(P \geq 0.16)$ prestorage bale characteristics; therefore, only main effects of initial bale moisture are reported and discussed. Overall, $(\mathrm{n}=35)$ bales averaged $286 \mathrm{~kg}$ in weight (wet basis), with a corresponding mean DM density of $188 \mathrm{~kg} / \mathrm{m}^{3}$. Initially, mean concentrations of bale moisture were $27.4,23.8$, and $19.6 \%$ for HM, MM, and LM hays, respectively. Length of LM bales was $0.08 \mathrm{~m}$ greater $(P<0.01)$ than MM bales, which also resulted in greater $(P=0.01)$ calculated bale volume (1.18 vs. $\left.1.14 \mathrm{~m}^{3}\right)$.

\section{Temperature Measurements}

Average 40-d bale temperature and HDD exhibited an interaction $(P=0.05)$ or tendency $(P=0.08)$ for interaction of main effects, respectively. Although MAX did not exhibit an interaction $(P=0.13)$, the overall trends were similar across treatments. For all 3 temperaturerelated response variables (Table 2), acid-treated HM bales exhibited less $(P<0.01)$ heating than untreated control hays; however, a rate effect also was observed in each case, with HM bales treated at the $0.6 \%$ level exhibiting more $(P \leq 0.02)$ heating than those hays receiving the greater $(1.0 \%)$ level. Overall, HM control hays accumulated 275 more HDD, and reached a MAX that was $11.4^{\circ} \mathrm{C}$ greater than $\mathrm{HM}$ hays treated at the $1.0 \%$ level. For MM and LM hays, heating was reduced $(P<0.01)$ by 212 HDD and 238 HDD, respectively, by applying the preservative at the $0.6 \%$ level relative to untreated control hays, but no further mitigation of heating $(P \geq 0.65)$ occurred by using the greater $1.0 \%$ application rate.

\section{Poststorage Bale Characteristics}

Following the 73-d storage period, final wet bale weights for the 1.0 and $0.6 \%$ acid-application levels were 26 and $24 \mathrm{~kg}$ greater $(P<0.01)$, respectively, than untreated control hays, and these differences can be largely explained on the basis of final concentrations of moisture in acid-treated bales (Table 3). Final moisture concentrations were greater $(P<0.01)$ by 4.0 to 5.0 percentage units for the acid-treated hays compared with the untreated controls, and were greater at the $1.0 \%$ application level compared with the $0.6 \%$ level (19.0 vs. $18.0 \% ; P<0.01)$. Dry bale weights only tended

Table 2. Temperature responses during a 73-d storage period for large rectangular bales of alfalfa-orchardgrass hay treated with propionic acid during baling

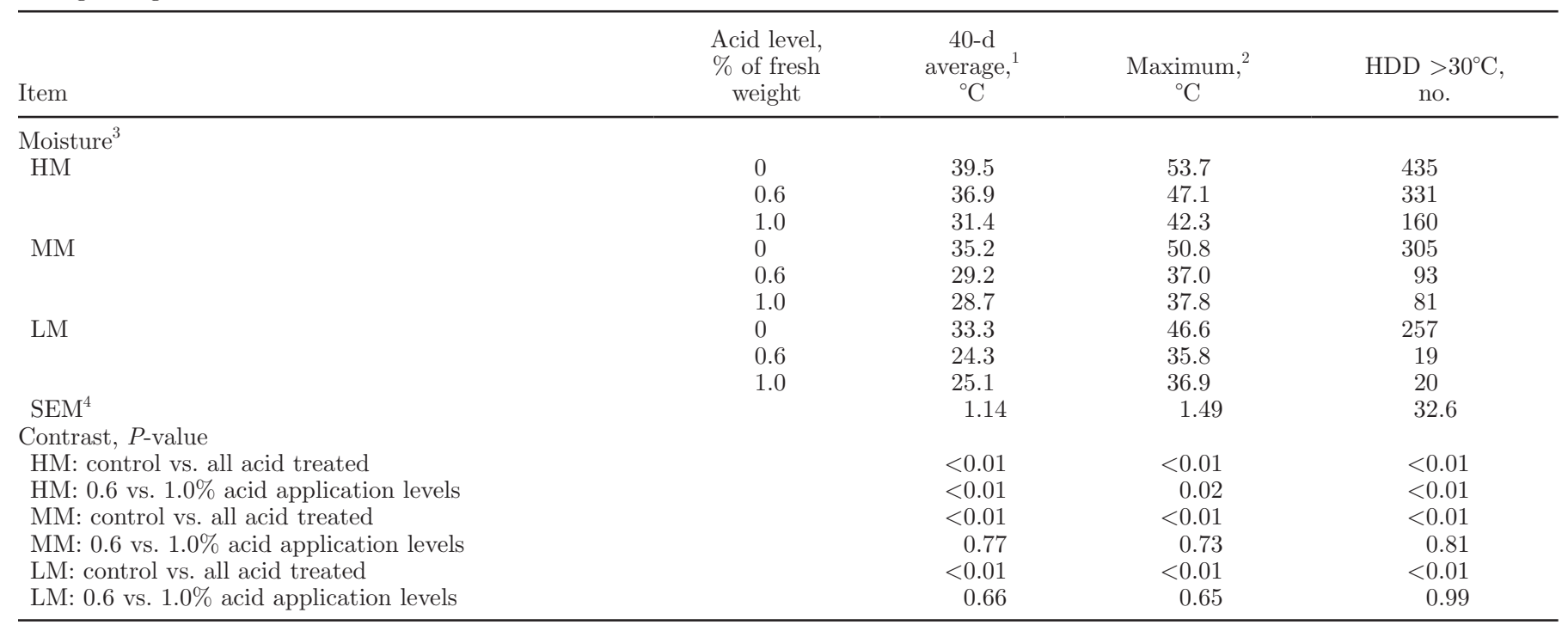

${ }^{1}$ Mean internal bale temperature during the first $40 \mathrm{~d}$ of storage. Day 40 represented the last day any bale accumulated heating degree days (HDD).

${ }^{2}$ Maximum internal bale temperature during a 73-d storage period.

${ }^{3} \mathrm{HM}=$ high-moisture $(27.4 \%)$ bales; $\mathrm{MM}=$ medium-moisture $(23.8 \%)$ bales; $\mathrm{LM}=$ low-moisture $(19.6 \%)$ bales.

${ }^{4}$ Pooled standard error of the interaction mean. 
$(P=0.07)$ to differ between acid-treated and untreated control hays, and the associated weight differential was only 10 to $11 \mathrm{~kg}$, which accounted for less than half of the differences observed for wet bale weights. Final bale dry weights also were affected by initial bale moisture; LM bales exhibited greater final dry weights than MM bales (222 vs. $208 \mathrm{~kg} ; P=0.04$ ), and MM bales tended have greater final dry weights than HM bales (208 vs. $196 \mathrm{~kg} ; P=0.07)$. Similar numerical trends were observed across bale-moisture groups for poststorage DM density, with MM bales exceeding HM bales by $9 \mathrm{~kg} /$ $\mathrm{m}^{3}(P=0.04)$. Finally, contrast analysis did not detect differences for recoveries of DM on the basis of preservative application rate $(P \geq 0.11)$, but prestorage bale moisture strongly affected recoveries of DM. The HM bales exhibited the poorest recoveries of DM, differing from MM bales by 3.3 percentage units (92.6 vs. $95.9 \%$; $P<0.01)$. Similarly, recoveries of DM were poorer for MM compared with LM bales (95.9 vs. $99.1 \%$; $P<$ 0.01 ), indicating that prestorage bale moisture, and not acid-application level, was the primary factor affecting poststorage recoveries of DM.

\section{Forage Nutritive Value}

Prestorage. On a prestorage basis, contrast analysis detected little difference among bales on the basis of moisture concentration, acid treatment, or the interaction of main effects; therefore, prestorage assessments of fiber components, ash, and TDN (Table 4), as well as those for CP, NDICP, and ADICP (Table 5), are averaged over all 35 experimental bales to simplify the presentation of results. Generally, the prestorage nutritive value of our experimental bales was consistent with tabular descriptions for mature, predominantly legume hays in which concentrations of NDF were $>50 \%$ (NRC, 2001).

Poststorage. For numerous indices of nutritive value, interactions of initial bale moisture and preservative application level were detected; therefore, all poststorage data describing nutritive value are presented and discussed as interaction means (Tables 4 and 5). Generally, concentrations of all fiber components (Table 4) increased during bale storage, regardless of treatment. For HM and MM bales, concentrations of NDF were greater $(P \leq 0.01)$ by 1.9 to 4.9 percentage units for untreated control bales compared with acidtreated bales, but no benefit $(P \geq 0.14)$ was associated with the greater acid application level $(1.0 \%)$ relative to the reduced level $(0.6 \%)$. Similarly, acid treatment reduced $(P=0.01)$ concentrations of hemicellulose in HM bales, and reduced concentrations of $\operatorname{ADF}(P<$ $0.01)$, cellulose $(P=0.01)$, and lignin $(P=0.02)$ in MM bales. However, no additional benefit $(P \geq 0.08)$ existed in any of these cases that could be associated with increasing the preservative application level from 0.6 to $1.0 \%$. Similar responses to treatment also were observed for whole-plant ash (Table 4) in HM bales. Concentrations of ash were greater $(P=0.05$; Table 4$)$ in untreated control bales compared with acid-treated hays, but no benefit $(P=0.46)$ existed that could be associated with increasing the preservative application level beyond $0.6 \%$. For whole-plant ash concentrations in MM bales, no significant $(P \geq 0.07)$ contrasts were

Table 3. Final bale characteristics for large rectangular bales of alfalfa-orchardgrass hay stored for $73 \mathrm{~d}$

\begin{tabular}{|c|c|c|c|c|c|c|}
\hline Item & $\underset{\mathrm{m}^{3}}{\text { Volume }}$ & $\begin{array}{c}\text { Wet bale } \\
\text { weight, } \\
\mathrm{kg}\end{array}$ & $\begin{array}{c}\text { Final } \\
\text { moisture, } \\
\%\end{array}$ & $\begin{array}{c}\text { Dry bale } \\
\text { weight, } \\
\text { kg }\end{array}$ & $\begin{array}{c}\mathrm{DM} \\
\text { density, } \mathrm{kg} \\
\text { of } \mathrm{DM} / \mathrm{m}^{3}\end{array}$ & $\begin{array}{c}\text { DM } \\
\text { recovery, } \\
\%\end{array}$ \\
\hline \multicolumn{7}{|l|}{ Treatment } \\
\hline \multicolumn{7}{|l|}{ Moisture group ${ }^{1}$} \\
\hline HM & 1.17 & 239 & 17.8 & 196 & 168 & 92.6 \\
\hline MM & 1.18 & 250 & 16.8 & 208 & 177 & 95.9 \\
\hline LM & 1.21 & 266 & 16.4 & 222 & 184 & 99.1 \\
\hline Control & 1.18 & 235 & 14.0 & 202 & 171 & 95.0 \\
\hline $0.6 \%$ & 1.21 & 259 & 18.0 & 213 & 177 & 96.1 \\
\hline $1.0 \%$ & 1.17 & 261 & 19.0 & 212 & 180 & 96.5 \\
\hline $\mathrm{SEM}^{2}$ & 0.015 & 5.3 & 0.20 & 4.5 & 3.1 & 0.62 \\
\hline \multicolumn{7}{|l|}{ Contrast, $P$-value } \\
\hline Moisture group: HM vs. MM & 0.79 & 0.14 & $<0.01$ & 0.07 & 0.04 & $<0.01$ \\
\hline Moisture group: MM vs. LM & 0.15 & 0.05 & 0.20 & 0.04 & 0.16 & $<0.01$ \\
\hline
\end{tabular}


Table 4. Final concentrations of fiber components, whole-plant ash, and TDN for large rectangular bales of alfalfa-orchardgrass hay

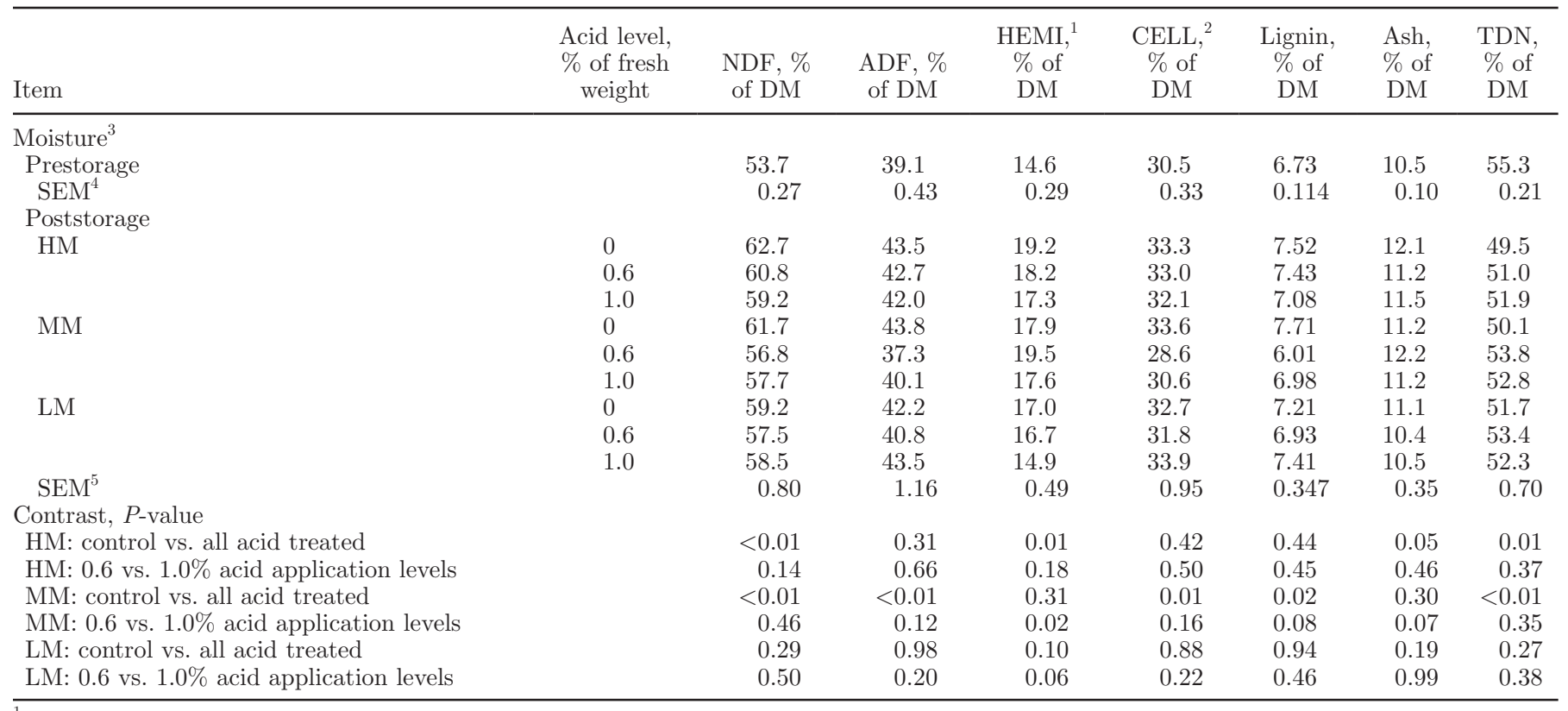

${ }^{1}$ Hemicellulose.

${ }^{2}$ Cellulose.

${ }^{3} \mathrm{HM}=$ high-moisture $(27.4 \%)$ bales; $\mathrm{MM}=$ medium-moisture $(23.8 \%)$ bales; and $\mathrm{LM}=$ low-moisture $(19.6 \%)$ bales.

${ }^{4}$ Standard error of the overall mean $(\mathrm{n}=35)$.

${ }^{5}$ Pooled standard error of the interactive mean.

Table 5. Final concentrations of CP components for large rectangular bales of alfalfa-orchardgrass hay

\begin{tabular}{|c|c|c|c|c|c|c|}
\hline Item & $\begin{array}{c}\text { Acid level, } \\
\% \text { of fresh } \\
\text { weight }\end{array}$ & $\begin{array}{l}\mathrm{CP}, \\
\% \text { of } \\
\mathrm{DM}\end{array}$ & $\begin{array}{c}\text { NDICP }{ }^{1} \\
\% \text { of } \\
\text { DM }\end{array}$ & $\begin{array}{c}\text { NDICP, } \\
\% \text { of } \\
\text { CP }\end{array}$ & $\begin{array}{c}\mathrm{ADICP}^{2} \\
\% \text { of } \\
\mathrm{DM}\end{array}$ & $\begin{array}{c}\mathrm{ADICP} \\
\% \text { of } \\
\mathrm{CP}\end{array}$ \\
\hline \multicolumn{7}{|l|}{ Moisture $^{3}$} \\
\hline $\mathrm{SEM}^{4}$ & & 0.13 & 0.11 & 0.63 & 0.051 & 0.27 \\
\hline \multicolumn{7}{|l|}{ Poststorage } \\
\hline HM & 0 & 17.8 & 7.84 & 44.1 & 2.71 & 15.3 \\
\hline \multirow{2}{*}{ MM } & 0.6 & 17.8 & 6.66 & 37.5 & 1.88 & 10.5 \\
\hline & 1.0 & 18.5 & 6.41 & 34.6 & 2.15 & 11.6 \\
\hline \multirow[t]{3}{*}{ LM } & 0 & 18.6 & 6.25 & 33.7 & 2.50 & 13.4 \\
\hline & 0.6 & 17.8 & 5.99 & 33.7 & 2.32 & 13.0 \\
\hline & 1.0 & 18.8 & 6.00 & 31.9 & 2.47 & 13.1 \\
\hline SEM $^{5}$ & & 0.31 & 0.203 & 1.22 & 0.200 & 1.07 \\
\hline LM: control vs. all acid treated & & 0.48 & 0.39 & 0.64 & 0.72 & 0.83 \\
\hline LM: 1.0 vs. $0.6 \%$ acid application levels & & 0.09 & 0.99 & 0.43 & 0.70 & 0.96 \\
\hline
\end{tabular}

${ }^{1} \mathrm{NDICP}=$ neutral detergent-insoluble CP.

${ }^{2} \mathrm{ADICP}=$ acid detergent-insoluble CP.

${ }^{3} \mathrm{HM}=$ high-moisture $(27.4 \%)$ bales; $\mathrm{MM}=$ medium-moisture $(23.8 \%)$ bales; and $\mathrm{LM}=$ low-moisture $(19.6 \%)$ bales.

${ }^{4}$ Standard error of the overall mean $(\mathrm{n}=35)$.

${ }^{5}$ Pooled standard error of the interactive mean. 
detected. Concentrations of TDN in HM and MM bales were improved $(P \leq 0.01)$ by 1.5 to 3.7 percentage units with acid treatment; however, in neither case $(P$ $\geq 0.35$ ) did the greater application rate offer additional improvement. For LM bales, no significant contrasts $(P$ $\geq 0.06$ ) were observed for any component of the foragefiber matrix, whole-plant ash, or estimates of TDN.

Generally, concentrations of CP, NDICP, and ADICP were greater on a poststorage basis compared with prestorage assessments. Not only did this prove to be true for NDICP and ADICP, but also for CP. Overall, the mean poststorage concentration of $\mathrm{CP}$ for all hays was 0.7 percentage units greater $(18.3$ vs. $17.6 \%)$ than observed on a prestorage basis. For HM bales, concentrations of $\mathrm{CP}$ (Table 5$)$ were greater $(P=0.02)$ for acid-treated hays compared with untreated controls, but no other significant $(P \geq 0.09)$ contrasts were detected, regardless of initial bale moisture. Concentrations of NDICP, expressed on both a percentage of DM and $\mathrm{CP}$ basis, were reduced $(P<0.01)$ in HM hays whenever the acid preservative was applied, resulting in differentials of 1.35 and 8.5 percentage units of DM and $\mathrm{CP}$, respectively, for hays treated at the $1.0 \%$ application level compared with untreated controls. When expressed on a percentage of DM basis, NDICP was also less $(P=0.01)$ when the $1.0 \%$ application rate was applied relative to the $0.6 \%$ level. Although not significant $(P=0.10)$, a similar numerical relationship between the 1.0 and $0.6 \%$ application levels was observed for NDICP expressed on a percentage of $\mathrm{CP}$ basis. Expressed on a percentage of DM basis, MM acid-treated hays exhibited less $(P=0.01)$ ADICP than untreated controls, and a similar numerical trend $(P$ $=0.16$ ) was observed for HM hays. When ADICP was expressed on a percentage of $\mathrm{CP}$ basis, concentrations were less in hays receiving acid treatment for both HM $(P=0.05)$ and MM $(P=0.02)$ bales, but clear benefits to the greater $1.0 \%$ application could not be detected $(P \geq 0.20)$. In LM hays, no discernible differences $(P \geq$ $0.39)$ existed for concentrations of NDICP and ADICP among baling treatments.

Regressions of Nutritive Value on Spontaneous Heating. Regressions of changes in nutritive value (poststorage - prestorage) on HDD or MAX are summarized in Table 6. Although the mean $\Delta \mathrm{CP}$ and $\Delta$ Ash were positive ( 0.7 and 0.9 percentage units, respectively) across all baling treatments, these concentration changes during bale storage could not be related to HDD or MAX $(P \geq 0.08)$ by any polynomial model evaluated. Regressions of $\triangle \mathrm{NDF}, \Delta$ hemicellulose, $\triangle \mathrm{NDICP}$, and $\triangle \mathrm{ADICP}$ on HDD or MAX all were best fitted to simple linear models in which the concentration increased ( $\Delta$ became more positive) with heating; in addition, each regression was characterized by rela- tively high coefficients of determination (overall range $=0.68$ to 0.85 ). Similarly, regressions of $\triangle \mathrm{ADF}$ and $\Delta$ cellulose on measures of heating were also best fitted to linear models with positive slopes, but coefficients of determination were somewhat poorer $($ range $=0.49$ to 0.60 ). Concentrations of lignin also increased with heating during bale storage, but the regression relationship with HDD was best fitted to a quartic model with a very high coefficient of determination $(\Delta$ lignin $=-0.00000000198 \mathrm{x}^{4}+0.00000168 \mathrm{x}^{3}-0.000428 \mathrm{x}^{2}+$ $\left.0.033 \mathrm{x}-0.32 ; \mathrm{R}^{2}=0.93\right)$. No relationship was found $(P$ $=0.08$ ) when MAX was substituted as the independent variable. Unlike all other dependent variables, concentrations of TDN declined linearly with heating, yielding slopes of 0.0083 percentage units per HDD $(\triangle \mathrm{TDN}=$ $\left.-0.0083 \mathrm{x}-1.9 ; \mathrm{R}^{2}=0.83\right)$, and 0.179 percentage units per degree Celsius of MAX $(\triangle \mathrm{TDN}=-0.179 \mathrm{x}+4.3$; $\left.\mathrm{R}^{2}=0.78\right)$.

\section{Apparent Digestibility of Hays in Growing Lambs}

Generally, significant main effects for daily intake and apparent digestibilities were accompanied by a significant bale moisture $\times$ acid preservative level interaction; therefore, all means are presented from this perspective. For DMI expressed on a grams-per-day basis (Table 7), no contrasts of acid-application level in balemoisture group existed that approached significance (overall mean $=667 \mathrm{~g} / \mathrm{d} ; P \geq 0.67$ ). Similar responses were observed on a percentage of BW basis, although a tendency $(P=0.06)$ existed for acid-treated hays to exhibit reduced intakes relative to untreated controls in HM bales (1.92 vs. $2.00 \%$ of BW). Benefits from application of the acid preservative were observed for MM bales for apparent digestibilities of both DM and OM. In both cases, apparent digestibilities were greater $(P$ $<0.01)$ for acid-treated hays compared with untreated controls, and were greater $(P \leq 0.01)$ for the $1.0 \%$ acid level compared with the $0.6 \%$ level, thereby demonstrating a clear application-level effect. These responses were not observed $(P \geq 0.23)$ for HM bales, where the mean apparent digestibilities were 52.4 and $52.0 \%$ of $\mathrm{DM}$ and OM, respectively. For LM bales, the apparent digestibility of DM was greater $(P=0.02)$ for hays treated at the $0.6 \%$ level compared with the $1.0 \%$ level (56.6 vs. $54.3 \%$ ), but other contrasts for apparent DM and $\mathrm{OM}$ digestibility were not significant $(P \geq 0.06)$. Overall, both apparent DM and OM digestibility could be related linearly to HDD through regression (Figures 1a and 1b). Relationships for DM $(\mathrm{Y}=-0.0080 \mathrm{x}+$ $\left.55.6 ; \mathrm{R}^{2}=0.46\right)$ and $\mathrm{OM}\left(\mathrm{Y}=-0.0084 \mathrm{x}+55.5 ; \mathrm{R}^{2}\right.$ $=0.52$ ) indicated that apparent digestibilities of both constituents declined by about 3.5 percentage units in the range of spontaneous heating exhibited by these 
Table 6. Regressions of changes (poststorage - prestorage) in nutritive value on heating characteristics for large rectangular bales of alfalfaorchardgrass hay treated with propionic acid preservative at levels of $0,0.6$, or $1.0 \%$ of wet bale weight

\begin{tabular}{|c|c|c|c|c|c|c|c|c|}
\hline Quality component $^{1}$ & $\begin{array}{l}\text { Independent } \\
\text { variable }^{2}\end{array}$ & $\mathrm{n}^{3}$ & Slope & $\mathrm{SE}_{\text {slope }}$ & Intercept & $\mathrm{SE}_{\text {intercept }}$ & $\mathrm{R}^{2}$ & $P$-value \\
\hline$\Delta \mathrm{NDF}, \%$ of $\mathrm{DM}$ & HDD & 9 & 0.0125 & 0.00248 & 3.2 & 0.58 & 0.79 & $<0.01$ \\
\hline$\Delta \mathrm{ADF}, \%$ of $\mathrm{DM}$ & MAX & 9 & 0.182 & 0.0602 & -5.4 & 2.62 & 0.57 & 0.02 \\
\hline \multirow{2}{*}{$\Delta$ Hemicellulose, $\%$ of DM } & HDD & 9 & 0.0041 & 0.00098 & 2.4 & 0.23 & 0.72 & $<0.01$ \\
\hline & MAX & 9 & 0.092 & 0.0221 & -0.8 & 0.96 & 0.71 & $<0.01$ \\
\hline \multirow[t]{2}{*}{$\Delta$ Lignin, $\%$ of $\mathrm{DM}$} & $\mathrm{HDD}^{5}$ & 9 & - & - & - & - & 0.93 & 0.01 \\
\hline & MAX & 9 & - & - & - & - & - & NS \\
\hline \multirow[t]{2}{*}{$\Delta$ Ash, $\%$ of DM } & HDD & 9 & - & - & - & - & - & NS \\
\hline & MAX & 9 & - & - & - & - & - & NS \\
\hline \multirow[t]{2}{*}{$\Delta \mathrm{CP}, \%$ of $\mathrm{DM}$} & HDD & 9 & - & - & - & - & - & NS \\
\hline & MAX & 9 & - & - & - & - & - & NS \\
\hline$\Delta \mathrm{NDICP}, \%$ of $\mathrm{DM}$ & HDD & 9 & 0.0037 & 0.00060 & 0.8 & 0.14 & 0.85 & $<0.01$ \\
\hline \multirow[t]{2}{*}{$\triangle \mathrm{ADICP}, \%$ of $\mathrm{CP}$} & HDD & 9 & 0.0104 & 0.00235 & 1.6 & 0.55 & 0.74 & $<0.01$ \\
\hline & MAX & 9 & 0.232 & 0.0530 & -6.4 & 2.31 & 0.73 & $<0.01$ \\
\hline \multirow[t]{2}{*}{$\Delta \mathrm{TDN}, \%$ of $\mathrm{DM}$} & HDD & 9 & -0.0083 & 0.00143 & -1.9 & 0.34 & 0.83 & $<0.01$ \\
\hline & MAX & 9 & -0.179 & 0.0363 & 4.3 & 1.58 & 0.78 & $<0.01$ \\
\hline
\end{tabular}

${ }^{1}$ Changes $(\Delta$; poststorage - prestorage) in concentrations of nutritive value during bale storage. NDICP $=$ neutral detergent-insoluble CP; $\mathrm{ADICP}=$ acid detergent-insoluble $\mathrm{CP}$.

${ }^{2} \mathrm{HDD}=$ heating degree days $>30^{\circ} \mathrm{C}$; MAX $=$ maximum internal bale temperature during storage.

${ }^{3}$ Number of treatment means in each regression.

${ }^{4}$ Test of significance for regression model.

${ }^{5}$ Regression of $\Delta$ lignin on HDD was best fitted by a quartic polynomial model: $\Delta$ lignin $=-0.00000000198 \mathrm{x}^{4}+0.00000168 \mathrm{x}^{3}-0.000428 \mathrm{x}^{2}+$ $0.033 \mathrm{x}-0.32\left(P=0.013 ; \mathrm{R}^{2}=0.93\right)$.

hays, and that HDD explained approximately $50 \%$ of the variability in DM and OM digestibility responses. For the apparent digestibility of NDF, differences were detected between the 1.0 and $0.6 \%$ application levels for MM (58.0 vs. $54.3 \% ; P=0.02)$ and LM bales $(52.3$ vs. $56.3 \% ; P=0.01)$. However these responses were inconsistent across bale moistures, and the overall linear regression of apparent NDF digestibilities on HDD indicated no relationship $(P=0.87)$ between fiber digestibility and spontaneous heating.

Analysis of apparent CP digestibility yielded no significant contrasts (overall mean $=85.8 \% ; P \geq 0.40$ ); however, a tendency $(P=0.09)$ existed for reduced apparent $\mathrm{CP}$ digestibility as affected by HDD ( $\mathrm{Y}=$ $-0.0038 \mathrm{x}+86.5 ; \mathrm{R}^{2}=0.35$; data not shown). Apparent digestibilities of NDICP exhibited no relationship with HDD $(P=0.74)$, but greater $(P=0.03)$ NDICP digestibility was observed for acid-treated MM bales relative to control hays, and an associated applicationlevel effect was observed in which the apparent NDICP digestibility of bales treated at the $1.0 \%$ level exceeded those produced at the reduced application level (80.6 vs. 75.4\%; $P=0.01)$. Apparent digestibilities for ADICP ranged from 11.4 to $38.4 \%$, yielding greater digestibilities for untreated controls relative to acid-treated hays in both HM (38.4 vs. $28.2 \% ; P=0.03)$ and LM bales (26.6 vs. $13.6 \% ; P=0.01)$. A mild rate effect $(P=0.05)$ also was observed for HM bales, but no contrasts were detectable $(P \geq 0.38)$ for MM hays. Overall, the linear relationship between apparent ADICP digestibility and HDD was the closest $\left(\mathrm{R}^{2}=0.67\right)$ of any total-tract digestibility constituent evaluated, yielding a positive slope $(\mathrm{Y}=0.041 \mathrm{x}+15.9 ; P=0.01 ;$ Figure 2$)$.

\section{DISCUSSION}

\section{Spontaneous Heating}

In this study, acid treatment reduced spontaneous heating in all bale-moisture groups (Table 2). For LM and MM bales, both preservative application levels yielded similar $(P \geq 0.65)$ reductions in 40 -d internal bale temperature, MAX, and HDD compared with untreated control hays. These observations suggest that there was little benefit when applying preservative at the $1.0 \%$ level to hays that were modestly moist 
Table 7. Daily intake of DM and apparent digestibilities of various forage components for large-rectangular bales of alfalfa-orchardgrass hay evaluated in growing lambs

\begin{tabular}{|c|c|c|c|c|c|c|c|c|c|}
\hline \multirow[b]{2}{*}{ Item } & \multirow{2}{*}{$\begin{array}{c}\text { Acid level, } \\
\% \text { of fresh } \\
\text { weight }\end{array}$} & \multicolumn{2}{|c|}{ DMI } & \multicolumn{6}{|c|}{ Apparent digestibility, ${ }^{1} \%$} \\
\hline & & $\mathrm{g} / \mathrm{d}$ & $\begin{array}{l}\% \text { of } \\
\text { BW }\end{array}$ & $\mathrm{DM}$ & $\mathrm{OM}$ & $\mathrm{NDF}$ & $\mathrm{CP}$ & NDICP & $\mathrm{ADICP}$ \\
\hline \multirow[t]{3}{*}{$\mathrm{HM}$} & 0 & 669 & 2.00 & 53.0 & 52.6 & 56.1 & 84.7 & 72.3 & 38.4 \\
\hline & 0.6 & 653 & 1.91 & 52.4 & 51.7 & 54.2 & 84.5 & 75.9 & 33.5 \\
\hline & 1.0 & 639 & 1.92 & 51.8 & 51.8 & 53.2 & 84.6 & 74.5 & 22.8 \\
\hline MM & 1.0 & 682 & 1.99 & 57.6 & 57.2 & 58.0 & 86.9 & 80.6 & 24.8 \\
\hline \multirow{3}{*}{ LM } & 0 & 675 & 2.06 & 54.6 & 54.6 & 52.8 & 87.3 & 71.8 & 26.6 \\
\hline & 0.6 & 677 & 2.03 & 56.6 & 56.0 & 56.3 & 86.6 & 76.1 & 15.7 \\
\hline & 1.0 & 675 & 2.00 & 54.3 & 54.2 & 52.3 & 85.7 & 68.0 & 11.4 \\
\hline $\mathrm{SEM}^{3}$ & & 44.7 & 0.037 & 1.56 & 1.63 & 1.60 & 1.21 & 1.67 & 3.67 \\
\hline \multicolumn{10}{|l|}{ Contrast, $P$-value } \\
\hline HM: control vs. all acid treated & & 0.67 & 0.06 & 0.23 & 0.26 & 0.07 & 0.91 & 0.07 & 0.03 \\
\hline
\end{tabular}

${ }^{1} \mathrm{NDICP}=$ neutral detergent-insoluble $\mathrm{CP} ; \mathrm{ADICP}=$ acid detergent-insoluble $\mathrm{CP}$

${ }^{2} \mathrm{HM}=$ high-moisture $(27.4 \%)$ bales; $\mathrm{MM}=$ medium-moisture $(23.8 \%)$ bales; and $\mathrm{LM}=$ low-moisture $(19.6 \%)$ bales.

${ }^{3}$ Standard error of the interactive mean.

$(<24 \%)$. In contrast, a clear preservative level effect was observed in HM bales; all measures of heating exhibited differences $(P \leq 0.02)$ between the 0.6 and $1.0 \%$ acidapplication levels, with the greater application level being more effective at suppressing spontaneous heating. Past studies evaluating the benefits of propionic acid-based preservatives on measures of spontaneous heating have produced mixed results. Several studies in which various formulations of propionic acid-based preservatives were applied to small rectangular bales (Sheaffer and Clark, 1975; Jafri et al., 1979; Rotz et al., 1991) have demonstrated clear reductions in heating characteristics for acid-treated moist hays compared with untreated controls. However, in one study (Rotz et al., 1991), acid treatment did not reduce HDD accumulations to levels comparable with dry $(\leq 20 \%$ moisture) hay controls. Results summarizing application of propionic acid products in large rectangular or large round hay packages have been less favorable. Shinners (2000) observed no measureable reductions in spontaneous heating in large rectangular bales of alfalfa hay treated with a propionic acid-based preservative compared with untreated controls. Similarly, Coblentz and Bertram (2012) found that HDD in 1.5-m (diameter) large round bales of alfalfa hay were reduced during the first $28 \mathrm{~d}$ of bale storage whenever the initial bale moisture was $\leq 38.1 \%$. Unfortunately, these benefits were lost in long-term storage, with untreated control hays accumulating less HDD than acid-treated hays over the entire storage period whenever the initial bale moisture was $\geq 27.7 \%$. Specific reasons for these inconsistent temperature responses over a wide range of bale types and baling conditions remain unclear.

In the current study, the final (73-d) concentrations of bale moisture for acid-treated hays were sharply elevated $(P<0.01$; Table 3$)$ compared with untreated control hays. This response to acid treatment has been noted consistently across studies (Rotz et al., 1991; Shinners, 2000; Coblentz and Bertram, 2012), and has been attributed to the hygroscopic nature of propionic acid (Rotz et al., 1991; Shinners, 2000). A potential consequence of these chemical responses is that biological activity may be increased or extended relative to untreated controls, and this phenomenon has been observed recently in large round bales (Coblentz and Bertram, 2012); in that study, recoveries of DM were not improved by acid treatment, and recoveries in both acid-treated and untreated hays were directly related to HDD in a homogeneous negative linear relationship $\left(\mathrm{Y}=-0.0066 \mathrm{x}+96.3 ; \mathrm{R}^{2}=0.75\right)$. Similar responses were observed in the present study, and recoveries of DM were explained again by a simple negative linear relationship with $\operatorname{HDD}\left(\mathrm{Y}=-0.016 \mathrm{x}+98.9 ; \mathrm{R}^{2}=\right.$ 0.60; data not shown).

\section{Nutritive Value}

Fiber Components. Concentrations of NDF, ADF, hemicellulose, cellulose, and lignin increased during storage (Table 4), and these responses were generally 
a)

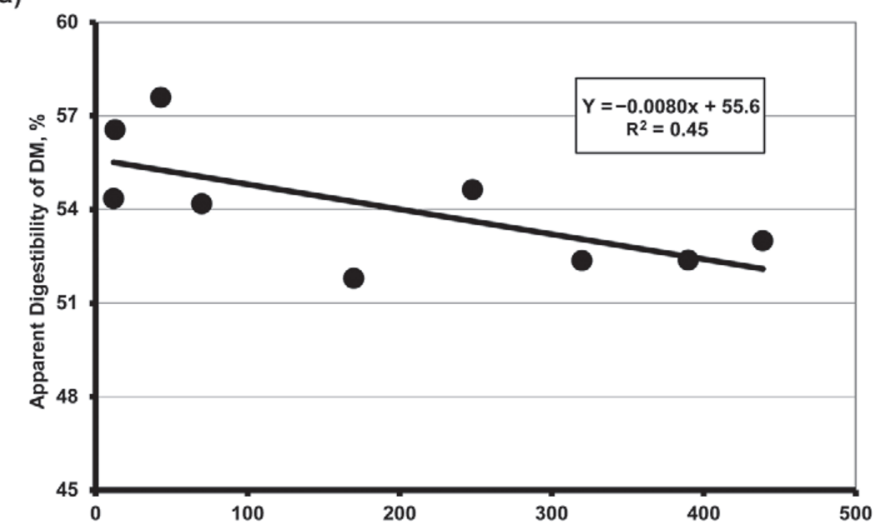

b)

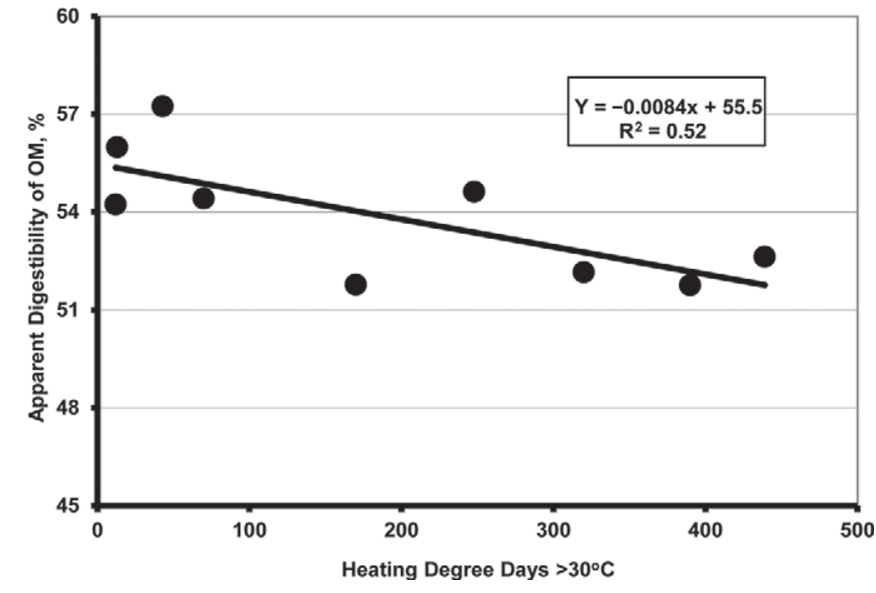

Figure 1. Apparent digestibilities of $\mathrm{DM}$ and $\mathrm{OM}$ in growing lambs for alfalfa-orchardgrass hays made at 3 bale moistures (19.6, 23.8, and $27.4 \%)$ and treated with a propionic acid-based preservative $(0,0.6$, or $1.0 \%$ of wet weight).

explained as positive linear functions of HDD or MAX (Table 6). As such, the effectiveness of acid treatment in limiting heating in HM and MM bales also yielded smaller increases in fiber components relative to untreated controls. Specifically, mitigated increases were observed for NDF $(P<0.01)$ and hemicellulose $(P=$ $0.01)$ in HM hays, as well as NDF $(P<0.01)$, $\operatorname{ADF}(P$ $<0.01)$, and lignin $(P=0.02)$ in MM hays. Generally, these improvements were modest, ranging from 1.9 to 4.9 percentage units of NDF, but demonstrate a clear response to acid treatment.

Linear increases in concentrations of fiber components as functions of HDD or MAX have been described previously for hays packaged in small rectangular bales, and include forages as diverse as bermudagrass (Coblentz et al., 2000; Turner et al., 2002) and alfalfa (Coblentz et al., 1996). However, regression relationships also are known to become curvilinear in large round bales that incur greater HDD or MAX (Coblentz and Hoffman, 2009b).

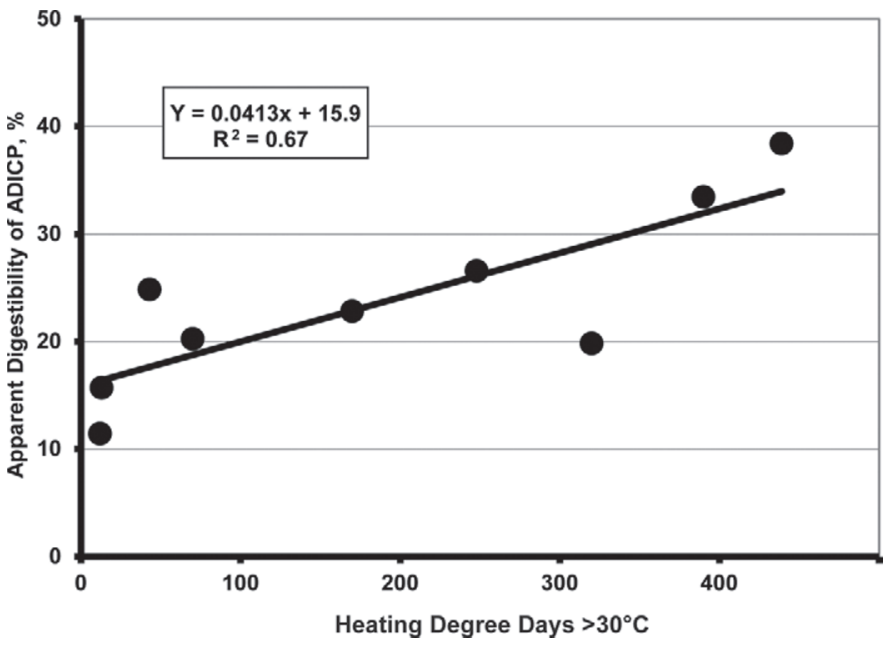

Figure 2. Apparent digestibilities of acid detergent-insoluble $\mathrm{CP}$ (ADICP) in growing lambs for alfalfa-orchardgrass havs made at 3 bale moistures $(19.6,23.8$, or $27.4 \%$ ) and treated with a propionic acid-based preservative $(0,0.6$, or $1.0 \%$ of wet weight).

Generally, these increases in fiber components occur via indirect mechanisms, and are presumed to be induced by oxidation of NSC (Coblentz et al., 1997), thereby increasing concentrations of more inert fiber components (Rotz and Muck, 1994). In the present study, a maximum accumulation of 435 HDD was attained by untreated HM bales; this range of heat accumulation was consistent with expectations for small rectangular bales (Coblentz et al., 1996; Coblentz et al., 2000; Turner et al., 2002), but far less than recent evaluations in large round bales, which reached maxima approaching 3,500 and $80^{\circ} \mathrm{C}$ for HDD and MAX, respectively (Coblentz and Hoffman, 2009a; Coblentz and Bertram, 2012). In the current study, no evidence existed of the biphasic response to heat by hemicellulose. In large round bales incurring severe heating, concentrations of NDF and hemicellulose increase indirectly until hemicellulose becomes a secondary reactive carbohydrate; at that point, concentrations of both analytes decrease as hemicellulose contributes to the formation of Maillard products, which are then recovered as artifact lignin (Goering et al., 1973; Coblentz et al., 2010).

CP and CP Components. Across all baling treatments, concentrations of $\mathrm{CP}$ increased by 0.7 percentage units relative to prestorage assessments (18.3 vs. $17.6 \%)$, but these changes could not be related directly to either $\operatorname{HDD}(P=0.81)$ or MAX $(P=0.87)$. Much like responses observed for fiber components, shortterm $(\sim 60 \mathrm{~d})$ increases in $\mathrm{CP}$ are believed to occur indirectly via disproportionate oxidation of NSC; however, these increases also may be blunted via volatilization of ammonia during long-term storage (Rotz and Muck, 1994). 
Concentrations of NDICP and HDD are known to be closely related, and this has been demonstrated in positive linear relationships for small rectangular bales of bermudagrass (Coblentz et al., 2000; Turner et al., 2002), and positive nonlinear relationships for large round bales of alfalfa-orchardgrass and alfalfa (Coblentz et al., 2010; Coblentz and Bertram, 2012). In the latter case, the regression relationship became increasingly asymptotic at the approximate upper limit of HDD accumulation observed in the current study (435 HDD; Table 2). Regardless of the bale type, forage species, or regression model, most of these previous regression relationships have been characterized by relatively high coefficients of determination, thereby suggesting that HDD, or other similar measures of heating, are the principle drivers regulating movement of $\mathrm{CP}$ from neutral detergent-soluble to neutral detergent-insoluble pools. Largely based on the direct effect that acid treatment had on suppressing temperature development in our experimental hay bales (Table 2), formation of NDICP was suppressed in HM bales, and similar numerical trends were observed in MM hays (Table 5).

Acid-treated hays exhibited reduced concentrations of ADICP (percentage of DM basis) relative to untreated control hays in MM bales, and in HM hays when ADICP was expressed on a percentage-of-CP basis. Past work (Coblentz et al., 2010; Coblentz and Bertram, 2012) has suggested that increased concentrations of ADICP in heated hays are partially associated with the biphasic response to heating observed for concentrations of hemicellulose. Historically, hemicellulose and soluble carbohydrates, especially sucrose, are thought to be the most reactive carbohydrates involved in the Maillard reaction (Van Soest, 1982; Van Soest and Mason, 1991). Concentrations of ADICP tend to increase linearly in heated alfalfa hays, often with very high coefficients of determination, until hemicellulose becomes a reactive carbohydrate contributing to the Maillard reaction, at which point the linear relationship between ADICP and HDD is lost, and ADICP increases with a more rapid curvilinear response pattern. Normally, the increments of heating incurred in small (45-kg) rectangular bales are not severe enough to be associated with apparent reactivity of hemicellulose or nonlinear increases in ADICP (Coblentz et al., 1996; Coblentz et al., 2000; Turner et al., 2002). Therefore, responses for $\mathrm{ADICP}$ in the 286-kg large rectangular bales produced in the present study were consistent with expectations for small $(46-\mathrm{kg})$ rectangular bale packages rather than large round bales weighing 500 $\mathrm{kg}$ or more.

Energy (TDN). Unlike all other response variables, estimates of TDN declined during storage, and these responses could be associated directly with HDD and
MAX, yielding relatively high coefficients of determination $\left(\mathrm{R}^{2}=0.83\right.$ and 0.78 , respectively; Table 6$)$. Improvements in TDN with acid treatment were modest, ranging from 1.5 to 3.7 percentage units, but differed $(P \leq 0.01)$ from untreated controls in $\mathrm{HM}$ and $\mathrm{MM}$ hays. Calculation of TDN was based on a summative approach (NRC, 2001) and, therefore, cannot be associated easily with any one nutritive index. Rather, this response represents collective improvement in nutritive value through modest reductions in concentrations of fiber components, NDICP, and ADICP in acid-treated hays relative to untreated controls.

\section{Digestibility of Hays}

Although the apparent digestibilities for DM and OM were affected $(P \leq 0.01)$ positively by acid treatment in MM bales (Table 7), these effects were erratic or nonexistent for HM and LM bales. For both nutritive constituents, linear regressions of apparent digestibilities on HDD were significant $(P \leq 0.05)$, but exhibited only modest coefficients of determination $\left(\mathrm{R}^{2} \geq 0.452\right.$; Figures $1 \mathrm{a}$ and $1 \mathrm{~b}$ ). Previously, total-tract evaluations of heated bermudagrass hays in growing lambs yielded similar negative linear relationships for apparent DM or OM digestibility on HDD that were characterized by relatively poor coefficients of determination $\left(R^{2}=0.37\right.$ and 0.43 , respectively; McBeth et al., 2001). Taken in total, these results suggest that reductions in apparent $\mathrm{DM}$ or $\mathrm{OM}$ digestibility were related directly to spontaneous heating. Furthermore, the absence of any relationship $(P=0.87)$ between apparent NDF digestibility and HDD for this data set indicates that reductions in apparent DM and OM digestibility likely were associated with respiratory losses of highly digestible NSC during storage (Rotz and Muck, 1994), thereby leaving a more fiber-laden and less-digestible hay.

Application of the propionic acid preservative had a marked effect on apparent digestibility of ADICP (Table 7), but this also appeared to be facilitated through its effects on spontaneous heating. Normally, ADICP is thought to be indigestible in ruminants (Van Soest, 1982), but several studies have shown that this may strictly apply only to ADICP in its native forms (Broderick et al., 1993; McBeth et al., 2001). Both of those studies reported negative apparent digestibilities of ADICP for unheated alfalfa and bermudagrass hays, but these estimates increased to approximately $40 \%$ of ADICP in response to steam or spontaneous heating, respectively. Generally, our results support these previous works; apparent digestibility estimates for ADICP ranged from a minimum of $11.4 \%$ for mostly unheated (20 HDD) hays up to $38.4 \%$ of ADICP for untreated HM bales. Furthermore, the relationship between ap- 
parent ADICP digestibility and HDD (Figure 2) was the closest of any of the nutritive indices evaluated $\left(\mathrm{R}^{2}\right.$ $=0.67$ ), and a similar positive linear relationship has been described for heated bermudagrass hays by McBeth et al. (2001). The positive relationship between apparent ADICP digestibility and HDD is somewhat counterintuitive; however, $\mathrm{CP}$ rendered insoluble in acid detergent by spontaneous heating during bale storage may retain some bioavailability, especially under the acidic conditions present in the abomasum and duodenum (McBeth et al., 2001).

\section{CONCLUSIONS}

Unlike previous work with large round bales, a propionic acid-based preservative was effective at limiting spontaneous heating in $0.8 \times 0.8 \times 1.7$-m large rectangular bales of alfalfa-orchardgrass hay. These benefits of acid application were observed at all 3 moisture concentrations evaluated, and a clear preservative level effect was observed for the HM bales. For MM and LM bales, both acid-application levels (1.0 and $0.6 \%)$ yielded comparable reductions in HDD relative to untreated controls. These reductions in spontaneous heating did not result in measurable improvements in recoveries of forage DM after storage. Although DM recovery was not improved by acid treatment, modest benefits in most indices of nutritive value were observed in treated hays, mostly in HM and MM bales. These modest benefits were generally related to indices of spontaneous heating in linear regression relationships, thereby indicating that benefits could largely be explained on the basis of alteration of normal heating patterns in hays. Similarly, apparent digestibilities of DM and OM in growing lambs declined linearly with HDD accumulated during bale storage, again demonstrating modest benefits associated with prestorage acid application to hays that were likely linked to perturbations of normal heating patterns. Based on these results, applying propionic-based preservatives to large rectangular bales is likely to provide good insurance against spontaneous heating during storage, as well as modest benefits with respect to nutritive value and digestibility. Some caution should be applied in interpreting these results; for statistical and logistical reasons, each bale in this study was stored independently, without contacting other bales. It remains unclear how the dynamics of the evaluation system might be altered by storing large rectangular bales in large stacks.

\section{REFERENCES}

AOAC International. 1998. Official Methods of Analysis, AOAC International Official Method No. 990.03. 16th ed., 4th rev. AOAC Int., Gaithersburg, MD.
Broderick, G. A., J. H. Yang, and R. G. Koegel. 1993. Effect of steam heating alfalfa hay on utilization by lactating cows. J. Dairy Sci. $76: 165-174$.

Buckmaster, D. R., and A. J. Heinrichs. 1993. Losses and quality changes during harvest and storage of preservative-treated alfalfa hay of varying moisture content. Trans. ASAE 36:349-353.

Coblentz, W. K., and M. G. Bertram. 2012. Effects of a propionic acidbased preservative on storage characteristics, nutritive value, and energy content for alfalfa hays packaged in large round bales. J. Dairy Sci. 95:340-352.

Coblentz, W. K., J. O. Fritz, K. K. Bolsen, and R. C. Cochran. 1996 Quality changes in alfalfa hay during storage in bales. J. Dairy Sci. 79:873-885.

Coblentz, W. K., J. O. Fritz, K. K. Bolsen, R. C. Cochran, and L. Fu. 1997. Relating sugar fluxes over time to quality changes in alfalfa hay. Agron. J. 89:800-806.

Coblentz, W. K., and P. C. Hoffman. 2009a. Effects of bale moisture and bale diameter on spontaneous heating, dry matter recovery, in vitro true digestibility, and in situ disappearance kinetics of alfalfaorchardgrass hays. J. Dairy Sci. 92:2853-2874.

Coblentz, W. K., and P. C. Hoffman. 2009b. Effects of spontaneous heating on fiber composition, fiber digestibility, and in situ disappearance kinetics of neutral detergent fiber for alfalfa-orchardgrass hays. J. Dairy Sci. 92:2875-2895.

Coblentz, W. K., and P. C. Hoffman. 2010. Effects of spontaneous heating on estimates of total digestible nutrients for alfalfaorchardgrass hays packaged in large round bales. J. Dairy Sci. 93:3377-3389.

Coblentz, W. K., P. C. Hoffman, and N. P. Martin. 2010. Effects of spontaneous heating on forage protein fractions and in situ disappearance kinetics of crude protein for alfalfa-orchardgrass hays packaged in large round bales. J. Dairy Sci. 93:1148-1169.

Coblentz, W. K., J. E. Turner, D. A. Scarbrough, K. E. Lesmeister, Z. B. Johnson, D. W. Kellogg, K. P. Coffey, L. J. McBeth, and J. S. Weyers. 2000. Storage characteristics and nutritive value changes in bermudagrass hay as affected by moisture content and density of rectangular bales. Crop Sci. 40:1375-1383.

Cochran, R. C., and M. L. Galyean. 1994. Measurement of in vivo forage digestion by ruminants. Pages 613-643 in Forage Quality, Evaluation, and Utilization. Nat. Conf. on Forage Quality, Evaluation, and Utilization. Univ. of Nebraska, Lincoln. G. C. Fahey Jr., M. Collins, D. R. Mertens, and L. E. Moser,ed. American Society of Agronomy, Crop Science Society of America, Soil Science Society of America (ASA, CSSA, SSSA), Madison, WI.

Collins, M., W. H. Paulson, M. F. Finner, N. A. Jorgensen, and C. R. Keuler. 1987. Moisture and storage effects on dry matter and quality losses of alfalfa in round bales. Trans. ASAE 30:913-917.

Goering, H. K., P. J. Van Soest, and R. W. Hemken. 1973. Relative susceptibility of forages to heat damage as affected by moisture, temperature, and pH. J. Dairy Sci. 56:137-143.

Jafri, S. A., L. J. Bush, and G. D. Adams. 1979. Chemical preservation of alfalfa hay for dairy cows. J. Dairy Sci. 62:455-458.

McBeth, L. J., K. P. Coffey, W. K. Coblentz, J. E. Turner, D. A. Scarbrough, C. R. Bailey, and M. R. Stivarius. 2001. Impact of heating degree-day accumulation during bermudagrass hay storage on nutrient utilization by lambs. J. Anim. Sci. 79:2698-2703.

NRC. 2001. Nutrient Requirements of Dairy Cattle. 7th rev. ed. National Academy Press, Washington, DC.

Rotz, C. A., R. J. Davis, D. R. Buckmaster, and M. S. Allen. 1991. Preservation of alfalfa hay with propionic acid. Appl. Eng. Agric. 7:33-40.

Rotz, C. A., and R. E. Muck. 1994. Changes in forage quality during harvest and storage. Pages $828-868$ in Forage Quality, Evaluation, and Utilization. Proc. Natl. Conf. on Forage Quality, Evaluation, and Utilization, Lincoln, NE. G. C. Fahey Jr., M. Collins, D. R. Mertens, and L. E. Moser, ed. American Society of Agronomy, Crop Science Society of America, Soil Science Society of America (ASA, CSSA, and SSSA), Madison, WI.

SAS Institute. 2002. SAS User's Guide: Statistics. Version 9.2. SAS Institute Inc., Cary, NC. 
Sheaffer, C. C., and N. A. Clark. 1975. Effects of organic preservatives on the quality of aerobically stored high moisture baled hay. Agron. J. 67:660-662.

Shinners, K. J. 2000. Evaluation of methods to improve storage characteristics of large square bales in a humid environment. Appl. Eng. Agric. 16:341-350.

Turner, J. E., W. K. Coblentz, D. A. Scarbrough, K. P. Coffey, D. W. Kellogg, L. J. McBeth, and R. T. Rhein. 2002. Changes in nutritive value of bermudagrass hay during storage. Agron. J. 94:109-117.

Van Soest, P. J. 1982. Nutritional Ecology of the Ruminant. Cornell University Press, Ithaca, NY.
Van Soest, P. J., and V. C. Mason. 1991. The influence of the Maillard reaction upon the nutritive value of fibrous feeds. Anim. Feed Sci. Technol. 32:45-53.

Van Soest, P. J., J. B. Robertson, and B. A. Lewis. 1991. Methods for dietary fiber, neutral detergent fiber, and nonstarch polysaccharides in relation to animal nutrition. J. Dairy Sci. 74:3583-3597.

Weiss, W. P., H. R. Conrad, and N. R. St. Pierre. 1992. A theoretically-based model for predicting total digestible nutrient values of forages and concentrates. Anim. Feed Sci. Technol. 39:95-110. 